\title{
Creativity as a factor in competitiveness on the international market
}

\section{Introduction}

An enterprise is an organisational system, meaning that it functions by the conscious organisational activities of those who set goals for it and who constantly direct the enterprise towards these goals in terms of its governance activities. ${ }^{1}$ One of the basic tasks in managing an enterprise is attaining the development that will enable the enterprise to maintain its existence in the market. The development of the enterprise creates opportunities and capabilities for new, more complex goals to rule the structure of relations in an enterprise. ${ }^{2}$ Always, prior to leaving one development stage and entering the next, more complex structures and relationships occur. It is characteristic of complex systems that they cannot be broken down into parts because that would put a veil over the characteristics of the system as a whole. Modern management theory accepts complexity as a basic characteristic of an enterprise, so chaos and managing complexity are management disciplines that are developing quickly. ${ }^{3}$ New acknowledgements of this matter help enhance organisational capabilities for innovation and the development of an enterprise. Traditional management viewed complexity as a problem that was to be dealt with via control and reduction, and even the total elimination of it in some cases, but new views see it as a condition that encourages creative potential. With the growth of complexity, the need for a new development programme grows concomitantly.

Enterprises as organisational systems tend towards the state of highest possibility, which is chaos. Chaos exhibits a natural tendency towards freedom until such point as it reaches disorganisation. Chaos is a specific form of complexity. It represents a total lack of order and of the differentiation of a system. The level of differentiation grows with the level of order in a system and the differences between different parts of a system are bigger. Entropy is a measure of chaos. To be able to manage an enterprise as a complex system, we need to countenance why these systems only work under three preconditions:

- openness, which allows the flow of energy, materials and information between the system and the environment

- the presence of imbalance because, otherwise, the rise of energy levels would, in the long run, stop the system from operating properly

- self-conferment, which allows for the reproduction of elements thus leading to system enhancement.

Bearing in mind that enterprises consist of technical, biological and organisational sub-systems that are heterogeneous, it is obvious that we need to focus on their har-

1 Kukoleča, S (1980) Osnovi teorije organizacionih nauka III izdanje: Beograd.

2 Komazec, G and M. Jovanović (2005) Upravljanje istraživanjem i razvojem Megatrend: Beograd.

3 Putnik, D. G (2006) Chaos and Complexity Management in Organizations: Basic Definitions and Some Research Topics SymOrg: Zlatibor 7-10 July 2006. 
monisation and on establishing symmetry through the process of managing development. Symmetry stands for force - the potential with which parts of the enterprise, and even the whole enterprise, comes together. In a broader sense, symmetry is the relationship of the whole towards the auto-expressed analogies in all shapes and sizes of time and space interceptions. ${ }^{4}$ Establishing symmetry between an enterprise and its parts is done simultaneously with harmonisation with the environment. Harmony and symmetry are two forces that drive changes; one of them is centripetal, or inner-directed; while the other is directed towards the outside - centrifugal.

\section{Basic hypothesis}

Managing enterprise development is carried out for several business reasons, some of which reflect technology and market dominance. New technologies provide real chances to attain competitive advantage on global markets. In countries in transition, such as Serbia for instance, the need for new technologies is especially underlined because of a significant lag behind developed countries. Transition, as an economic idea, stands for the change of the socialist countries of the former USSR and those that gravitated from the planned to the market economy at the end of the eighties of the last century. It starts with macroeconomic elements and seeks to establish a stability of the economic system. Stability should help the conversion of enterprises to a new way of doing business. Transition is also tied to privatisation which embodies a change of ownership structure. It is thought that private ownership is more competitive in modern business because it should be more effective, efficient, and profit-oriented. Enterprises should be in the ownership of those who have greater financial power, better management, longer experience and more sophisticated technology.

Starting with the hypothesis that, in modern economies, both macro and micro elements exist in co-operation, ${ }^{5}$ it can be concluded that, based on the results of the last fifteen years of Serbian economics, it is necessary to put much more effort into the management of enterprises. The basic macro-economic problem of Serbia is that it is one-sided and directed towards maintaining macro-economic stability whereas its development component, raising the competitiveness of the national economy and the politics of investment are being neglected. Management structures should be focused on two groups of problems:

- searching for, developing and supporting different sources of innovation

- creating an atmosphere of market competition in which innovation is taken for granted as a pre-condition not only for growth but for survival as well.

The basic question is how to ignite enterprises in the direction of development. The transition period can last a long time, and even technology that was new at the beginning of this process is now old and out of date. Enterprise organisation is also an issue because, in the meantime, new organisational structures supported by ICT have developed. However, human resources seems to be the biggest problem; motivation is becoming one of the dominant problems for managers in developing countries. Un-

4 Petrović, V (2005) Analogija i entropija - filozofija prirode $i$ harmonije Laze Kostića $i$ Koste Stojanovića Matica Srpska: Novi Sad.

5 Levi-Jakšić, M, S. Marinković and G. Komazec (2004) 'Kooperativni menadžment inovacija - nacionalna politika i strategija preduzeća' Poboljšanje performansi preduzeća uslov poslovanja u evropskom okruženju Megatrend: Beograd, 10 December. 
certainty concerning a job position is not only an effect of privatisation but also one of globalisation. From research carried out in Croatia, ${ }^{6}$ employees looked to privatisation firstly to assure their positions and then to raise their standard of living and enterprise efficiency and, lastly, improve the distribution of wealth.

The hypotheses on which this study is based are:

\begin{tabular}{|l|l|}
\hline $\mathrm{H}_{0}$ & Creativity gives a chance to under-developed enterprises \\
\hline $\mathrm{H}_{1}$ & Anybody can be creative \\
\hline $\mathrm{H}_{2}$ & $\begin{array}{l}\text { Of the three basic components of creativity - expertise, creative skills and motivation - } \\
\text { the last-named is the biggest problem }\end{array}$ \\
\hline $\mathrm{H}_{3}$ & Managers must be expected to set the grounds for motivation \\
\hline $\mathrm{H}_{4}$ & The creative combining of available knowledge enables the creation of new technologies \\
\hline $\mathrm{H}_{5}$ & $\begin{array}{l}\text { New technologies provide the opportunity for a successful breakthrough into interna- } \\
\text { tional markets }\end{array}$ \\
\hline $\mathrm{H}_{6}$ & New technologies will develop faster and better in co-operation \\
\hline
\end{tabular}

\section{Testing the hypothesis}

$\mathrm{H}_{5}$ and $\mathrm{H}_{6}$

The importance of technology for development does not need to be particularly underlined; it is sufficient just to mention American enterprises that, through technological supremacy, have achieved great results in international markets. What characterised the Serbian economy up until recently were massive systems that were intended to seem as one large business. We were often able to see enterprises that had facilities, business buildings, large number of employees, broad strategies, accounting procedures, etc. The past gave us something tangible. ${ }^{7}$ The technological potential came from intellectual capital and the power of the mind, attributes that tend not always to be tangible.

This can be confusing to some people because it is in our nature that we are generally better able to accept and understand things that we can put our hands on. Previously, it used to be whole institutions, with their rules and values, on which an individual could rely. Now, we are free in every way; to work, think and become whatever we want to. Of course, along with this comes responsibility for our own actions. Knowledge is hard to define. The very notion of its loose form gives an individual a feeling of psycho-social disorientation. Even the power of the mind of a single person cannot be determined because this is shaped by different situations in different time and space intervals; and how could we, then, determine the power of mind of all the employees of an organisation?

It is also important to underline that technological development is carried out in co-operation. The technological development of an enterprise is dependent upon suc-

6 Peračković, K (2001) Factors of Job Insecurity in Croatia Institute of Social Sciences Ivo Pilar: Zagreb http://www.hsd.hr/revija/pdf/3-4-2002/Perackovic.pdf

7 Riderstrale, J and K. Nordstrom (2002) Funky business Book house Publishing AB: Stockholm. 
cess in managing the national system of innovation, the level of investment in IR and the level of innovation derived from those investments. For example, the US has enjoyed a level of growth of $10 \%$ for scientific-technological alliances over the past two decades. At the same time, the presence of high-end technology in the total export activities of an industry has risen to $20 \%$ compared to $10 \%$ in 1980 . The increase in work productivity has been doubled compared to the mid-nineties and unemployment is at its lowest in the last three decades. ${ }^{8}$

Technological development comes out of innovation that is the result of learning, where different knowledge is being combined or new knowledge created. Carriers are IR enterprises, second business unit enterprises, buyers, suppliers, government institutions, universities, etc. The development of an enterprise via technological innovation is a result of complex co-operation: enterprises; the NIR institute; university; professional communities; education and information infrastructure; financial institutions; government agencies; and public resources. In US, around $23 \%$ of all alliances are established for R\&D purposes while western Europe has a figure of $14 \%$ and Asia around $12 \% .{ }^{9}$ Enterprises rarely operate development programmes on their own. The reasons for this are various, some of the most important ones being:

- the faster allocation of resources and skills

- the acquisition of some necessary abilities and resources which lowers the involvement of the means and raises personal flexibility

- co-operation with partners creates an opportunity for learning

- sharing costs and project risks

- developing a common standard, especially for complementary products and competitive prices.

The most common shapes of co-operation between enterprises are strategic alliances, mutual investments, licensing, outsourcing and mutual research organisations. Co-operation with universities and government institutions is being carried out between the offices for technology transfer, scientific and technological facilities, incubators, non-profit organisations, clusters and spillovers. Serbian enterprises are not as connected as they should be, while co-operation with universities and institutes is not at the desired level. According to the results of recent research, Serbia is among the countries with lower absorption capacities, meaning a less-developed national innovation system. ${ }^{10}$

$\mathrm{H}_{4}$

Innovation is made by combining different knowledges or creating new ones. Disruptive innovation is a result of available knowledge leading to a shortage of those elements with which buyers are familiar, such as product performance. Sustainable technological advances are the result of the work of innovators by which product performances are enhanced in a way which can be seen by buyers in accordance with the established values of the leading market group. Disruptive innovation creates an en-

8 Popper, W. S and S. C. Wagner (2002) New Foundations for Growth: The US Innovation System Today and Tomorrow RAND, January, p. 13.

9 Schilling, A. M (2005) Strategic Management of Technological Innovation McGraw-Hill/ Irwin.

10 Kutlača, Đ (2006) Apsorptivni kapacitet kao ključna komponenta nacionalnog inovacionog kapaciteta SymOrg: Zlatibor, 7-10 July 2006. 
tirely different market approach. For most of the time, this does not come from existing industry leaders who rarely ever create disruptive innovation. The reason for this should be looked for within the value chain. Industry leaders, day by day, year by year, are developing new products, enhancing old ones and looking for alternatives to buyer value. However, disruptive innovation comes from enterprises that have no routine in the way they do business. Bearing in mind that disruptive products usually bring less profit from a unit, they are not particularly interesting to industry leaders. Disruptive innovation can go either upwards in relation to the performances of the main flow of the consumption of production, ${ }^{11}$ or downwards. ${ }^{12}$

Sustainable innovation usually creates familiar, existing organisations while disruptive organisations are usually the product of new enterprises able to shake up even the dominant industry leaders. A typical example of this would be FedEx, which started providing delivery services for business mail to certain clients in the seventies, having recognised that clients highly valued the speed and reliance of mail delivery. Once it had mastered its business, it added more clients and became a serious competitor to the US Postal Service which, at the time, held a monopoly on the market. The profits they gained ensured the resources for their next development project - a two-day delivery. They lowered business costs, cut prices and extended the client base. Another example, which went the opposite way, downwards first, were the mini iron mills. These mills were simple and cheap enough that even buyers without outstanding purchasing power could afford them, although these mills were of lower quality. When this obstacle was overcome, they started to dominate the market. Opportunities for market entrance in this way is the myopia of large and strong enterprises which are too focused on the fine-tuning of their businesses that they often overlook what is going on in the market. On the other hand, these are usually large enterprises with large capacities and mass production techniques, and not necessarily over-focused on smaller buyers.

Different internal conflicts can also represent a problem leading to an inability to cash in on the changes. Large enterprise managers need to be very careful with disruptive innovation because they can not only change the existing organisational structure but also destroy core competencies. Disruptive innovation is usually used by enterprises that rely on the creative potential of employees that are stimulated by an adequate set of motivational factors different for each individual. By encouraging the differences between each individual and their confrontation, we create innovation. The power of internal motivation based on self-image shows a correlation with the internalised goals of an organisation. Research shows that, if during the process feedback about competencies and values is unconditional, an individual is more likely to accept the conditions of an organisation in which he/she works. ${ }^{13}$ It is important to underline the level of dedication an individual shows in performing these tasks. Endurance is as important as creative potential. Therefore, innovation derived from the symbiosis between endurance and creativity can easily shake the foundations of the market leader, whose strategy of innovation consists of incremental improvements.

11 Christensen, M, C (1997) The Innovator's Dilemma: When New Technologies Cause Great Firms to Fail Harvard Business School Press: Harvard.

12 Carr, G. N 'Top-Down Disruption: The Innovators' Strategy+Business 39.

13 Mladenovic, M (2007) Predstava o sebi i motivacija za rad Zadužbina Andrejevic: Beograd. 
In making decisions about the type of innovation, business leaders should take into consideration three factors: resources; personal processes; and their value. ${ }^{14}$ It is important to give extra attention to the relationship between the values of the existing processes. A matrix concerning this issue helps managers better understand which team should work on a development project and the kind of organisational structure that they will need: ${ }^{15}$

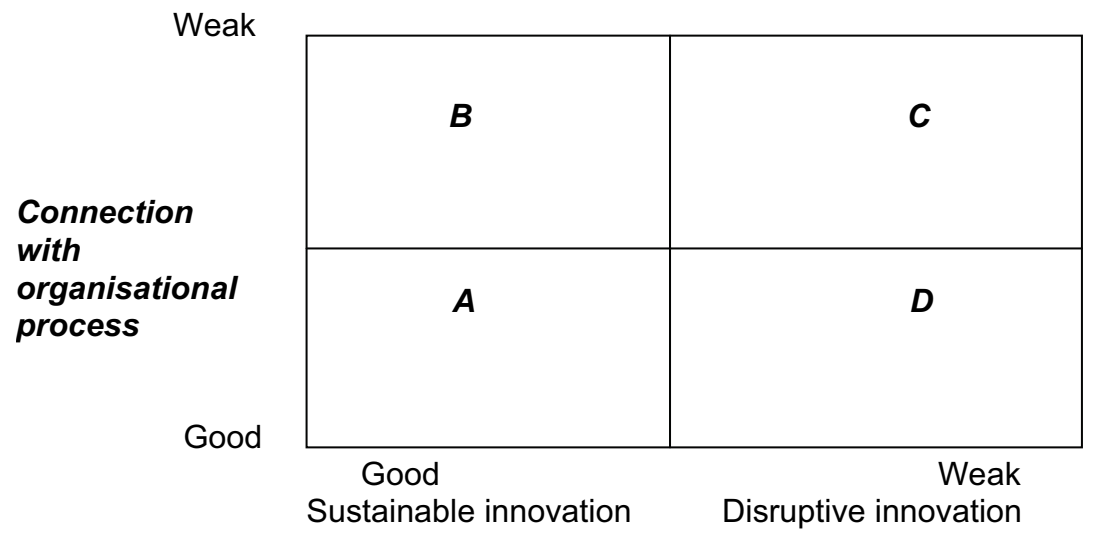

Connection to organisational value

\begin{abstract}
A Using a light category team, or the functional team of the existing organisation B Using a heavy category team inside the existing organisation.

C Using a heavy category team in a different organisation - spin-outs

D Development can be within the enterprise with a heavy team, but commercialisation is always looking for spin-outs
\end{abstract}

In defining an approach for disruptive innovation, it is necessary to determine the proportion of the market segment that can be disruptive. This segment consists of two groups of buyers - those that are under-served and those that are over-served by a product. ${ }^{16}$ Those that have more than they need from a product often complain about its complexity and its high price. Some values are not tangible as far as they are concerned and, therefore, they are not going to pay for the next generation of that product. Concerning the other group that does not use the product, it is characteristic either that better marketing is required or that they just do not have enough money for it. They have no capability, money or approach which lends itself to conventional and easy product development; someone is usually hired to do it for them or otherwise much hard work goes into obtaining a less adequate solution.

14 Christensen, M. C and M. Overdorf (2001) 'Meeting the Challenge of Disruptive Change' On Innovation, Harvard Business Review: Harvard Business School Publishing Corporation.

15 ibid.

16 Johnson, W. and M. Eyring (2004) A Diagnostic for Disruptive Innovation HBSWK Publishing, 9 August. 
$\mathrm{H}_{3}$

In creating disruptive innovation, it is necessary to observe less noticeable changes in the market and think twice about existing products. These activities are different and carry out the linear flow of operations for the creation of sustainable innovation in different ways, demanding a higher level of both employee and entrepreneur creativity. Creativity affects the organisation and, vice versa, the organisation can encourage or suppress creativity. The influence of the organisational environment towards creativity can be shown as follows: ${ }^{17}$

Figure 1 - Encouraging a creative atmosphere

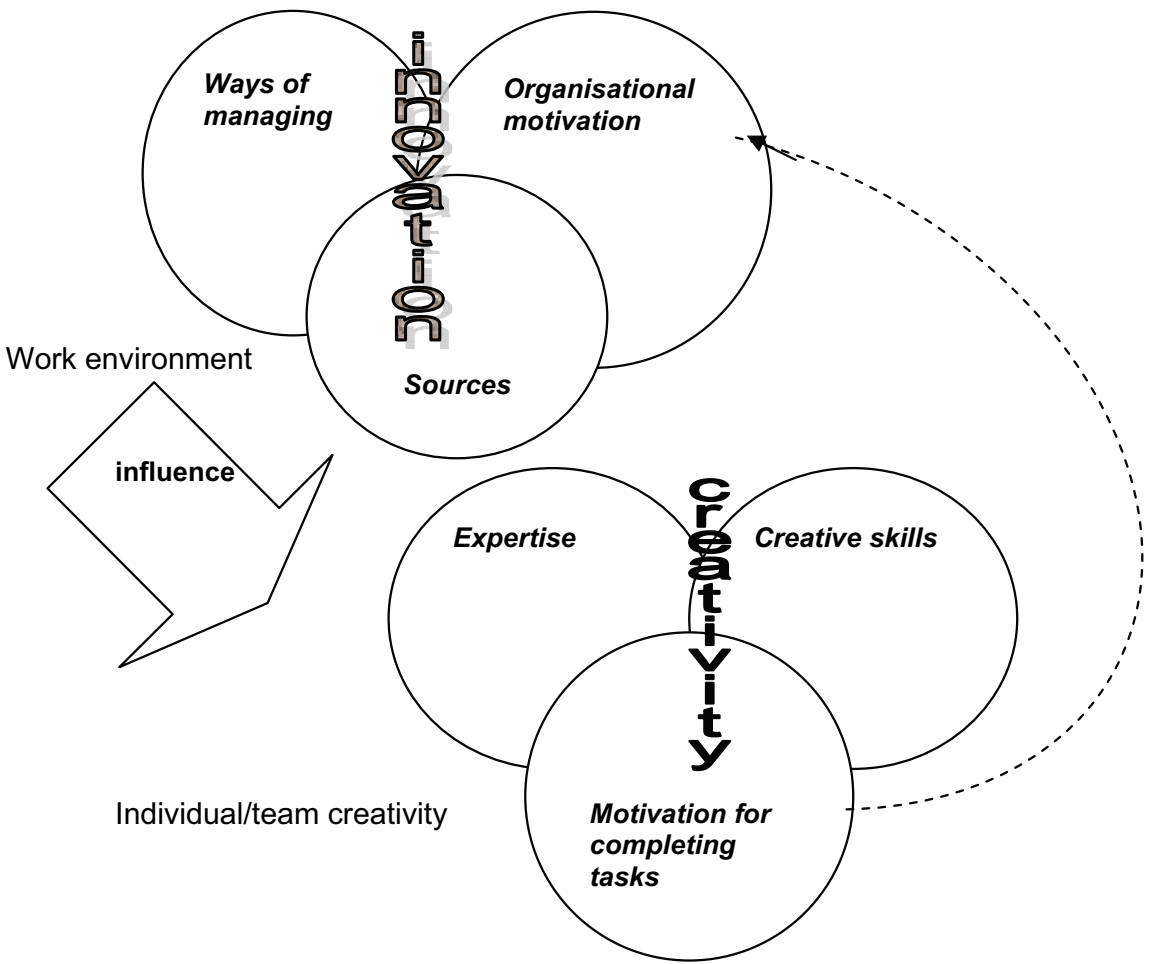

Managers and leaders must stimulate employees towards creativity and innovativeness. They need to develop a culture and structure that will help transfer the creative thoughts of employees into practical ideas for innovation. However, all employees are not motivated by the same factors. Motivation factors are split into two categories: those that are tied to the job itself; and those that are tied to the environment. The first group contains job responsibility, autonomy in work and greater satis-

17 Amabile, M. T (1996) Creativity and Innovation in Organizations Harvard Business School, 9-396-239, 5 January. 
faction at completing complicated tasks successfully; while environmental factors include pay, safety and working conditions.

Some people are more oriented towards intrinsic awards while others prefer external sources of motivation: as outside motivation grows, the internal one tends to get smaller. However, under certain conditions, outside motivation will not have negative effects on intrinsic motivation and can even lead to the opposite effect regarding the development of creativity. External motivators such as awards and recognition for creative work, clearly-defined project goals and constructive reverse connections have a positive effect on creativity. The initial level of motivation is also especially important because if the stances and motives of a person are exposed to external effects, this means that the stances and motives are unclear. In contrast, when these are strong and clear, there is a positive effect on intrinsic motivation. Each person has his or her own set of values that is not co-existent with those of others. Therefore, the process of motivation must be approached from the perspective of an individual rather than that of a group.

Figure 2 - The model of transformation of creative ideas of employed into ideas for innovation ${ }^{18}$
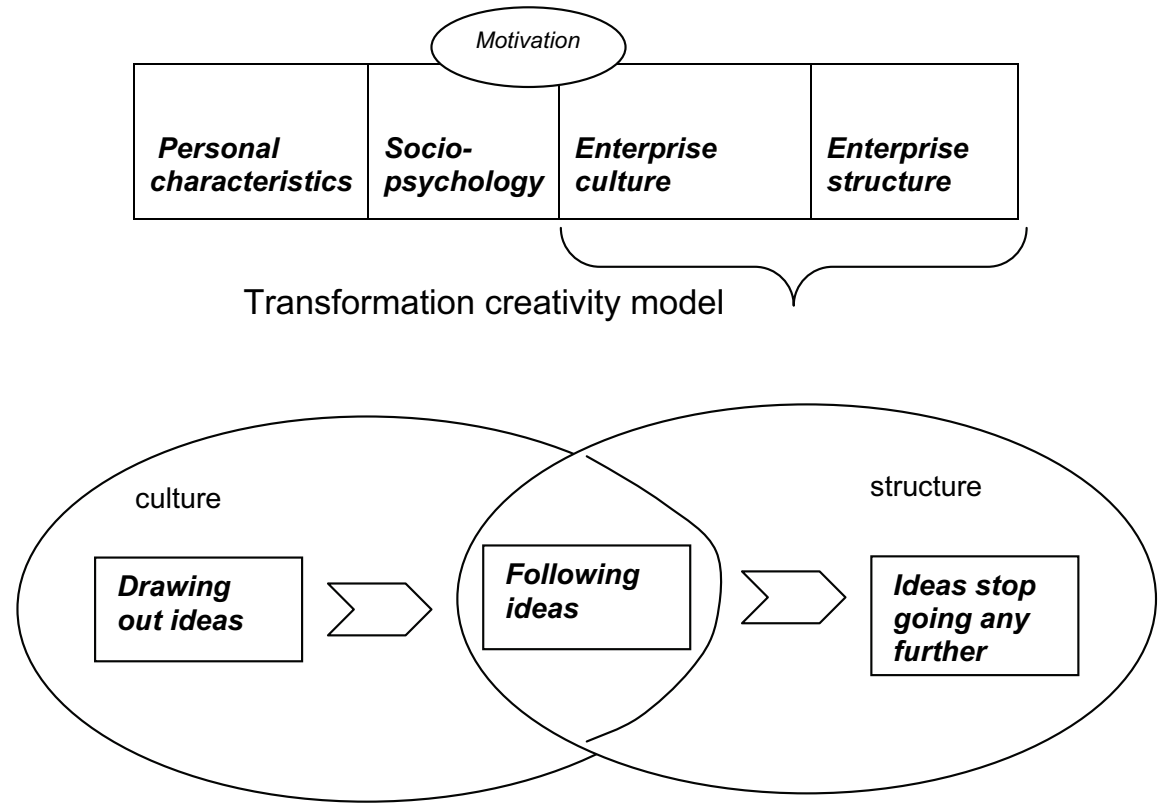

18 Van Dijk, Ch and J. Van den Ende (2002) 'Suggestion systems: transferring employee creativity into practicable ideas' $R \& D$ Management 32, May: Blackwell Publishers Ltd. 
Managers need to encourage creativity through the formulation of ideas and the sharing of knowledge within an enterprise, such as in the following model: ${ }^{19}$

\section{Figure 3 - Model of formulating and sharing ideas}

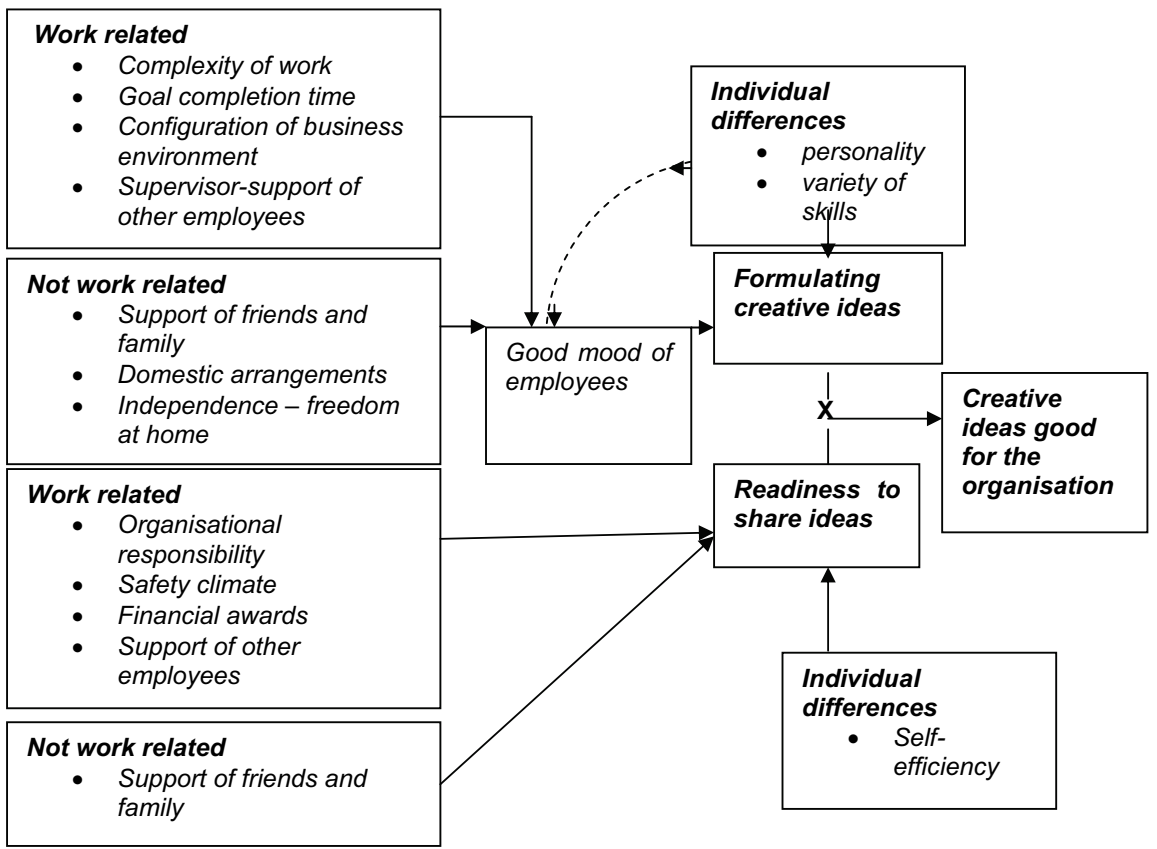

Research into a sample of 49 employees in two timber production industry enterprises in Serbia, Inter drvo and Compo, show that Serbian managers do not encourage a creative atmosphere. The responses of employees to a set of pre-determined questions were as follows:

\begin{tabular}{|l|c|c|c|c|}
\hline & $\begin{array}{c}\text { Inter } \\
\text { drvo }\end{array}$ & Compo & Total & $\%$ \\
\hline I think about enhancing the work I do: & 6 & 6 & 12 & 24 \\
\hline Often & 5 & 18 & 23 & 47 \\
\hline Sometimes & 13 & 1 & 14 & 29 \\
\hline Never & & &
\end{tabular}

19 Oldham, R. G (2003) 'Stimulating and Supporting Creativity in Organizations' in Managing Knowledge for Sustainable Competitive Advantage, Designing Strategies for Effective Human Resource Management Jossey-Bass: A Wiley Imprint. 


\begin{tabular}{|c|c|c|c|c|}
\hline & $\begin{array}{l}\text { Inter } \\
\text { drvo }\end{array}$ & Compo & Total & $\%$ \\
\hline \multicolumn{5}{|c|}{ At home I take some time to think about improving at work: } \\
\hline Every day & 5 & 5 & 10 & 20 \\
\hline When I have the time & 3 & 6 & 9 & 18 \\
\hline I'm not motivated to improving at work & 7 & 4 & 11 & 22 \\
\hline I don't think about it & 9 & 10 & 19 & 39 \\
\hline \multicolumn{5}{|l|}{ The possibility of creative thinking at work: } \\
\hline Does not motivate me & 8 & 4 & 12 & 24 \\
\hline Motivates me a little & 6 & 2 & 8 & 16 \\
\hline Neither motivates nor does not motivate me & 5 & 7 & 12 & 24 \\
\hline Motivates me & 4 & 10 & 14 & 29 \\
\hline Definitely motivates me & 1 & 2 & 3 & 6 \\
\hline \multicolumn{5}{|c|}{ The level of responsibility, freedom of decision and autonomy in work: } \\
\hline Does not motivate me & 14 & 1 & 15 & 31 \\
\hline Motivates me a little & 5 & 2 & 7 & 14 \\
\hline Neither motivates nor does not motivate me & 2 & 8 & 10 & 20 \\
\hline Motivates me & 2 & 11 & 13 & 27 \\
\hline Definitely motivates me & 1 & 3 & 4 & 8 \\
\hline \multicolumn{5}{|l|}{ Improving relations between workers: } \\
\hline Does not motivate me & 10 & 1 & 11 & 22 \\
\hline Motivates me a little & 7 & 1 & 8 & 16 \\
\hline Neither motivates nor does not motivate me & 3 & 10 & 13 & 27 \\
\hline Motivates me & 4 & 11 & 15 & 31 \\
\hline Definitely motivates me & 0 & 2 & 2 & 4 \\
\hline
\end{tabular}

Only $24 \%$ of workers think about how to improve and innovate at work, while $29 \%$ never think about it. It is interesting that an equal proportion of workers on both sides often think about promotion, while there is a significant difference between those who answered that they rarely or never think about it: Inter drvo has around $50 \%$ of workers who said that they never think about it, while Compo had only $4 \%$. 
The differences in responses here also come from differences in work experience. The youngest surveyed workers at Inter drvo had worked there for at least two years, while the other enterprise had $50 \%$ of those interviewed who had worked there for less than two years. According to job category, about $90 \%$ were manual workers while $10 \%$ were managers. Additionally, there was a significant difference in age structure: half the sample were under 40 years old while the other half was over 40 .

However, there was a significant difference between them as far as their interest in enhancing the business of the enterprise was concerned: $46 \%$ of the sample at Inter drvo was not interested in the improvement of the enterprise, while $80 \%$ of that at Compo was very interested in this. There was also a difference in terms of a justification for the change of ownership structure. $80 \%$ of workers at Compo thought that the enterprise was doing better since its privatisation, while $58 \%$ of those at Inter drvo thought that nothing had really changed. Workers at Compo had a positive opinion about the success of privatisation and $60 \%$ were confident of the success of the enterprise, while $32 \%$ were not as confident about their job position. At the other enterprise, $4 \%$ of workers thought privatisation would help the business, while $79 \%$ worried about their job.

In conclusion, we can point out that there is a significant difference between the atmospheres in the two enterprises: in Inter drvo it is negative, while in Compo it is quite positive. In spite of these differences, the percentage of workers who want to contribute to improving the business is around the same. This is supported by the hypothesis that managers were not sufficiently focused on the creation of a creative atmosphere. Workers surveyed were not interested in making the business better. Over $60 \%$ of them were not sufficiently motivated even to think about it at home, while most workers responded that they were motivated towards creativity very little or not at all. In this matter, they were not interested in autonomy in work, freedom of decision-making or responsibility. About an equal number was interested in bettering relations between their fellow employees. This indicates that the level of co-operation is not at the desired level and that joint working would probably result in failure.

If we consider the number of registered patents as one of the pointers for creativity, Serbia's trend of registering patents has been in decline from 1991 to 2003. At the same time, the number of registered patents is declining in relation to announced ones. ${ }^{20}$ For instance, out of 848 announced patents, only three were registered in 2000 and, in 2001, only 42 out of 935 . Over $90 \%$ of patents are the result of the work of an individual whereas less than $8 \%$ come from enterprises and only $1 \%$ comes from institutes. These indicators directly confirm that creativity and the involvement of managers in the field of creativity is low.

$\mathrm{H}_{2}$

Motivation as an element in creativity is the key factor in the development of innovation. In Serbia, where the unemployment rate stands at $32 \%$, motivation is at very low levels: workers cannot be happy just by knowing that they have work, while dissatisfied workers are not getting satisfaction from work and not even success at work

20 Kokeza, G (2006) Naučno-istraživačke aktivnost kao osnova razvojnog potencijala SymOrg: Zlatibor, 7-10 July 2006. 
could make them happy. A satisfied person has a better motivation to work and study. Motivation to work often brings good results to workers and inspires them to further success although success itself can make a person happy only for a short period of time.

In the survey, only $50 \%$ of those questioned were motivated by the level of safety at work and $20 \%$ were definitely dissatisfied. That they only work in the given enterprise because of the lack of opportunity to work elsewhere also does not motivate them. In relation to motivation factors, external factors are based on rewards and are also not stimulatory: the level of income motivates $35 \%$ of workers while a further $14 \%$ is highly motivated by this factor; in contrast, $31 \%$ are not motivated by it at all. Similar answers were also given concerning the continuity of payment. In relation to internal factors, more workers were less motivated on the issue of promotion. Even fewer than this were motivated by professional improvement while about $50 \%$ were not interested in the social status their job provided them.

\begin{tabular}{|c|c|c|c|c|}
\hline & $\begin{array}{l}\text { Inter } \\
\text { drvo }\end{array}$ & Compo & Total & $\%$ \\
\hline \multicolumn{5}{|l|}{ Job safety motivates me: } \\
\hline Does not motivate me & 7 & 3 & 10 & 20 \\
\hline Motivates me a little & 1 & 2 & 3 & 6 \\
\hline Neither motivates nor does not motivate me & 4 & 6 & 10 & 20 \\
\hline Motivates me & 11 & 14 & 25 & 51 \\
\hline Definitely motivates me & 1 & 0 & 1 & 2 \\
\hline \multicolumn{5}{|c|}{ I do this because I have no other options and thus this job: } \\
\hline Does not motivate me & 8 & 2 & 10 & 20 \\
\hline Motivates me a little & 8 & 3 & 11 & 22 \\
\hline Neither motivates nor does not motivate me & 4 & 8 & 12 & 24 \\
\hline Motivates me & 2 & 10 & 12 & 24 \\
\hline Definitely motivates me & 2 & 2 & 4 & 8 \\
\hline \multicolumn{5}{|l|}{ The salary level for this job: } \\
\hline Does not motivate me & 10 & 5 & 15 & 31 \\
\hline Motivates me a little & 2 & 3 & 5 & 10 \\
\hline Neither motivates nor does not motivate me & 0 & 5 & 5 & 10 \\
\hline Motivates me & 9 & 8 & 17 & 35 \\
\hline Definitely motivates me & 3 & 4 & 7 & 14 \\
\hline
\end{tabular}




\begin{tabular}{|c|c|c|c|c|}
\hline & $\begin{array}{l}\text { Inter } \\
\text { drvo }\end{array}$ & Compo & Total & $\%$ \\
\hline \multicolumn{5}{|l|}{ Payment continuity: } \\
\hline Does not motivate me & 9 & 6 & 15 & 31 \\
\hline Motivates me a little & 1 & 2 & 3 & 6 \\
\hline Neither motivates nor does not motivate me & 3 & 4 & 7 & 14 \\
\hline Motivates me & 8 & 10 & 18 & 37 \\
\hline Definitely motivates me & 3 & 3 & 6 & 12 \\
\hline \multicolumn{5}{|l|}{ Opportunity for promotion: } \\
\hline Does not motivate me & 8 & 4 & 12 & 24 \\
\hline Motivates me a little & 6 & 2 & 8 & 16 \\
\hline Neither motivates nor does not motivate me & 3 & 7 & 10 & 20 \\
\hline Motivates me & 5 & 9 & 14 & 29 \\
\hline Definitely motivates me & 2 & 3 & 5 & 10 \\
\hline \multicolumn{5}{|l|}{ Personal prosperity: } \\
\hline Does not motivate me & 8 & 8 & 16 & 33 \\
\hline Motivates me a little & 6 & 3 & 9 & 18 \\
\hline Neither motivates nor does not motivate me & 5 & 2 & 7 & 14 \\
\hline Motivates me & 3 & 7 & 10 & 20 \\
\hline Definitely motivates me & 2 & 5 & 7 & 14 \\
\hline \multicolumn{5}{|l|}{ The social status this job provides me: } \\
\hline Does not motivate me & 13 & 7 & 20 & 41 \\
\hline Motivates me a little & 3 & 1 & 4 & 8 \\
\hline Neither motivates nor does not motivate me & 0 & 3 & 3 & 6 \\
\hline Motivates me & 6 & 12 & 18 & 37 \\
\hline Definitely motivates me & 2 & 2 & 4 & 8 \\
\hline
\end{tabular}

$\mathrm{H}_{1}$

It is considered that there is no solid evidence that creativity is a natural ability received by everyone at birth. ${ }^{21}$ Therefore, anyone who invests a certain effort in themselves can be creative. Maslow said: 
A man must be only what he can be.

The phenomenon of loyalty is often connected to creativity. Employees are connected to an organisation as a result of the connections and contacts they establish with colleagues alongside whom they work. This is especially obvious in teams because here the different values of each worker are brought into play. Small teams have the highest levels of loyalty: a seven-person team has fifteen points more on the loyalty scale than a 25-member team. If team members are loyal and motivated with the right set of motivation factors characteristic to themselves, creative potential will be especially encouraged and it will lead to enterprise harmony. Even with all the benefits that teamwork brings, however, everyday strong connections to certain workers will eventually result in negative energy and 'group thinking' ${ }^{22}$

It is a matter of informed stances and perspectives that lead to a decrease in initiative, originality and agility.

$\mathrm{H}_{0}$

Creativity gives a chance to under-developed enterprises, because it is a very cheap and available resource. To take advantage of creative potential, it is necessary for managers to invest much more effort in creating an atmosphere that supports creativity. To be able successfully to complete these tasks, they will need to educate themselves as regards the types of motivation, their sources and effects on performance and the different influences that can be directed towards motivation. The main problem in reaching this goal in Serbia is the low level of initial motivation of both workers and managers. This problem could be resolved by hiring managers with a high level of emotional intelligence. According to Trebenstein, emotionally intelligent leaders are resonant, meaning their enthusiasm, energy and passion are always accepted happily. They have a healing affect on the group, whose members feel confident because they are emotionally connected, feel solidarity and make decisions jointly. Thanks to the leader's emotions, members of the group feel accepted, safe, understood and supported which helps them maintain composure and confidence in conditions of major changes and crises.

Encouraging creative atmosphere at the individual level is realised by support for open thinking and the chance to experiment and analyse a problem in its broad application. This means that leisure time during work should be restructured: workers should be given some time to exclude themselves from everyday routine tasks. They need to have quiet, just like people resting in the evening are finding time for the next consensus that allows them to anticipate when and by which rules some paths should be added and which allows the nerve centres to manage their own unique action of nerve paths. ${ }^{23}$ According to the laws of nerve conductors, if a nerve path has been recently used, it gains an advantage in the choice of path in a new situation. With each use of a pathway, its chances grow of being used again which would eventually lead to the individual becoming like a robot. The brain combats this with the use of differ-

21 Jerotić, V (1988) Psihoanaliza i kultura Četvrto izdanje, Biblioteka XX veka: Beograd.

22 Brajovic, K (2007) 'Kolektivna apatija' Ekonomist magazin: Beograd.

23 Ognjenović, P and B. Škorc (2005) Naše namere i osećanja, Uvod u psihologiju motivacije i emocija Gutenbergova galaksija: Beograd. 
ent mechanisms. The basic problem of the brain is not in how to remember something but in how to forget: how to erase something that has been used and which is no longer needed. These mechanisms regulate the competencies of certain nerve centres that are used alternatively to maintain the flexibility of the system. Sleep is what gives the brain the refreshment necessary to react in an unfamiliar situation. When a person is thinking about a problem that has an infinite number of solutions, such as innovation, then a decision on the solution is dependent upon numerous factors such as heritage, cognitive abilities, temperament, social effects and the situations this person has come across in the past.

In creating decisions that involve actions with a great deal of freedom, consciousness is what prevails. Abel's research (at St. John's University, USA) shows that creativity gives a chance to small enterprises. He studied the creation of innovation in large American high technology enterprises, coming to the conclusion that these enterprises get their ideas most of the time from smaller and unknown enterprises. Their negotiation power, combined with logistical support, drives them to commercialise the innovation, not to create it. This means that the Icarus paradox becomes stronger. By this notion, it is understood that some large and successful firms are unable to respond to technological challenges because they are too focused on market success. They have well-developed procedures and development policies, but this leads to routine which reacts against creativity.

\section{Conclusion}

This article suggests that, in the present conditions, enterprises in Serbia should be more focused on managing development. Special attention needs to be paid to the development of new technologies. Strategic orientation should be focused towards new combinations of existing knowledge, with the goal of satisfying the specific desires of buyers that are not satisfied and/or are over-served with the existing product. This strategy should also be aimed towards people i.e. employees. Creativity is typical for human beings, regardless of the level of education, and this creates a solid base for development.

To encourage creativity, employees should be motivated. Motivation is based on a combination of internal and external factors. The problem of creating synergic effects between both types of motivation is the level of initial motivation, which has deviated due to the transition. Internal motivation, which should be a basis for creativity, is really not very strong. It is necessary to reduce the pressure for completing work and for rewards to be given only for achieved results: employees should be given the opportunity to think, experiment and find pleasure in work and they should be able to express their thoughts and suggestions freely and spontaneously. To achieve this, managers and business leaders need to set their minds towards motivation, study this complex system and lead by example. 